\title{
Philadelphia, First ACRL Chapter
}

\author{
Mr. Trezza, head of the Circulation De- \\ partment, University of Pennsylvania Li- \\ brary, is president of the Philadelphia Chap- \\ ter of $A C R L$.
}

$\mathrm{I}^{\mathrm{N}}$ JUNE of I950 the Special Libraries 1 Association formally dissolved its national University and College group. Many of the local chapters of the Special Library Association had active University and College groups and these local groups were faced with the serious problem of deciding what their future would be. In Philadelphia, the University and College group appointed a Reorganization Committee to consider its future. The Committee sent out a questionnaire in April 195 I with the following five suggested courses of action and the implications of each:

\section{"I. Become an independent, local group.}

This would entail the development of a full program of meetings, projects, etc., as well as sufficient dues to finance the meetings, programs, etc. It would also mean the establishment of 'another library association.'

"2. Affliate with the Pennsylvania Library Association.

Under the present constitution of PLA, there is no provision for a special interest group such as ours. PLA chapters are all geographical units. ${ }^{1}$

"3. Become a chapter of the Association of College \&o Reference Libraries.

As there is no local chapter of ACRL here, this would entail development of a full program of meetings, projects, etc. Dues would be those of ALA membership, plus local chapter dues. Chapter membership would necessitate ALA membership. ${ }^{2}$

1 Actually, PLA does have special interest sections, - including College and Reference.

2 It was learned later that chapter membership does not necessitate ALA or national ACRL membership.

\section{"4. Continue as a Division of the Special Libraries Council of Philadelphia and Vicinity.}

As members of SLA or local members of the Council only, Division members would share fully in local SLA meetings and activities. Membership in such a local division would not affect the individual right to affiliate with other, national divisions. Dues in addition to SLA membership (local or national) would be necessary in order to finance a worthwhile program.

"5. Disband."

A meeting of the members of the University and College group was held June I, 195 I, to consider the results of the questionnaire. Forty-three per cent of the members answering the questionnaire voted in favor of becoming a local chapter of ACRL, 26 per cent favored continuing as a division of the Special Libraries Council of Philadelphia, 16 per cent voted to disband altogether, and 15 per cent voted to affiliate with the Pennsylvania Library Association.

In accordance with these results, the University and College group dissolved as a section of S.L.C. A committee, comprised of Carola Baus, the Reverend Daniel P. Falvey, O.S.A., Walter Hausdorfer, and Alphonse F. Trezza, chairman, was then formed. On July 5, 195 I, a letter was sent to all ACRL members in the Southeastern Pennsylvania, Southern New Jersey and Delaware areas requesting them to sign a petition for the formation of a regional chapter of ACRL. Seventy-five members signed such petitions which were, in turn, submitted to the ACRL Board of Directors in early October. Official recognition of 
the Philadelphia Chapter of ACRL was announced by the end of October. Thus, the first regional chapter of ACRL came into being.

The organizational meeting of the new Philadelphia Chapter was held April 22, 1952. At this meeting Arthur T. Hamlin, Executive Secretary of ACRL, spoke on the relations between national and local ACRL. Consideration and adoption of a constitution was the next item on the program. After a very lively discussion and much pruning, the proposed constitution was accepted. The chairman of the committee for organizing a Philadelphia chapter of ACRL was then instructed to appoint a nominating committee, plan the next meeting, and have the constitution reproduced in final form.

The second meeting of the Philadelphia Chapter of the ACRL was held in the auditorium of the Free Library of Philadelphia on February 17, 1953. The report of the election of officers, held by mail, was given by Mr. John P. McDonald (Head of Reserve Book Department, University of Pennsylvania Library) in his capacity as chairman of the Nominating Committee. He stated that the Nominating Committee had decided to try to get "a slate that had, above all else, good balance; that is, a variety of local institutions represented by candidates, a fair division between men and women, and use of young blood along with older and presumably wiser heads." Ten institutions were represented on the ballot and seven men and five women accepted nominations. Ballots were mailed to approximately 100 persons. Seventy completed ballots were returned in two weeks. The following officers were announced as elected:

President, Mr. Alphonse F. Trezza (Head, Circulation Department, University of Pennsylvania)

Vice-President \& President Elect, Miss Martha A. Connor (Technical Services
Librarian, Swarthmore College Library)

Secretary-Treasurer, Mrs. Edith W. Finch (Business Librarian, Temple University)

Director (I-year term), Mr. Walter Hausdorfer (Librarian, Temple University)

Director (2-year term), Miss Jane Walker (Head Cataloger, Bryn Mawr College Library)

Director (3-year term), Dr. Charles W. David (Director of Libraries, University of Pennsylvania)

The term of the elected officers, according to the constitution, begins at the end of the Spring meeting.

A panel discussion was then held, with lively audience participation, on the problems of reserve book department administration in college and university libraries. The institutions represented were Haverford College, Lincoln University, Temple University, University of Pennsylvania, and Villanova University making it possible for views of a variety of sizes and types of libraries to be represented.

On Saturday, May 16, I953, the Philadelphia Chapter of ACRL held a day-long meeting jointly with the eastern regional group of the College and Reference Section, Pennsylvania Library Association at LaSalle College. In a brief business meeting the president announced that the ACRL chapter officers officially assumed office at the end of this Spring meeting, that the Chapter now had 53 dues paying members, that membership should be solicited in each college library by some present member, that copies of our constitution would be available to members in the Fall.

Mr. Walter W. Wright, chairman of the College and Reference Section, PLA, conducted a business meeting for the PLA chapter. Of special interest to ACRL members was his mention of the great overlapping of membership and interests between the ACRL and PLA chapters there as- 
sembled. The question Mr. Wright raised was whether two organizations so similar should exist side by side.

Brother Edmund Joseph, librarian of LaSalle College, then spoke to the group about his new library building, the problems in its planning and the resultant good features, and invited the group to tour the building before and after lunch. The guest speaker of the morning session was Mr. Lyle Boulware, architect of the new library building. $\mathrm{He}$ spoke on contemporary architecture: its functionalism, its expression of modern life, its reasonable cost, its utilization of latest and best materials and engineering.

In the afternoon the group reassembled in the library building for the afternoon panel session on "Library BuildingsDreams vs. Realities." Mr. Walter Hausdorfer presented general principles and desiderata for library buildings, Dr. Harriet D. MacPherson spoke of plans for a new building for Drexel Institute of Technology library and library school. Dr. Charles W. David spoke of the long-term planning and many frustrations along the road to a new library building for the University of Pennsylvania. And Mr. Lee C. Brown spoke of the newly completed library building of the Pennsylvania Military College. The Reverend Daniel P. Falvey, O.S.A., led the panel discussion. All the participants and the audience agreed on the need for strong leadership by the librarian in long and careful planning, a close and reciprocal relationship between the librarian and architect, and sufficient expenditure to assure a building which will meet needs for many years to come, and require a minimum of upkeep.

With the close of this meeting came the end of the formative period of the first local chapter of ACRL. A petition for permission to organize was circulated, submitted and approved; a constitution was proposed, altered and accepted. Officers were nominated and elected. Three program meetings have been held. The committee for the organization of the Philadelphia chapter of ACRL did its work well. A solid foundation was laid on a broad base of wide participation. The future of the new organization is now in the hands of its elected officers. Hard work, leadership with some imagination, and the whole-hearted cooperation of all the librarians in the area will go a long way to insure the success of the Philadelphia Chapter of ACRL.

(Note: Copies of the Constitution of the Philadelphia Chapter of ACRL are available from Mr. Trezza.)

\section{A-V Round Table to Organize at Minneapolis}

At the Midwinter Meeting of ALA, authorization was granted by ALA's Council for the establishment of an Audio-Visual Round Table. If you are interested in membership in the Round Table write to Ira Peskind, Membership Chairman, Wright Junior College, $3400 \mathrm{~N}$. Austin Ave., Chicago 34, Ill. Also watch the May AL.A Bulletin for the date, place and time of the Round Table's organization meeting in Minneapolis. 